\title{
NORD STREAM 2: LITMUS TEST FOR EUROPEAN UNITY
}

\author{
Arūnas Molis \\ PhD Pol. Sci. \\ Angela Aiello \\ MA \\ Simona Sglavo \\ MA
}

\begin{abstract}
Despite the attempts to classify Nord Stream 2 natural gas pipeline as a 'purely commercial' project, its political dimension is undisputed. In the long run, this project may have significant security and solidarity implications for both Baltic Sea region states and the entire European Union. This paper attempts to analyse risks that would derive from the implementation of the Nord Stream 2 project, presenting some options for the European Union to prevent or postpone the construction of the pipeline. The ultimate aim is to highlight the political dimension of the project and introduce arguments that the EU member states (MSs) may use in order to resist the project. The probability that the European Union will stay strong and united in this context is also an object of this research.
\end{abstract}

Key words: European Union, Russia, natural gas pipeline, Nord Stream, the Energy Union

\section{Introduction}

According to the European Commission (EC), the basic objectives of the European Energy Union are 'an open and competitive internal energy market, security of energy supply and solidarity within the Union'. Therefore, the diversification of energy routes, sources and suppliers is a necessary premise to ensure better interconnections between Member States (hereinafter MSs), towards a more efficient internal market. ${ }^{1}$ Gazprom states that Nord Stream 2 would be in line with EU's objectives of competitive, secure and sustainable energy: energy security would be ensured, thanks to the new infrastructures and lower level of $\mathrm{CO}_{2}$ emissions

1 European Commission (2017) 
(in comparison to the coal), the competitiveness can be enhanced by direct links to the most efficient gas reserves. ${ }^{2}$ In the light of these diverging approaches, there is no wonder that since few years ago the 'NS2' gas pipeline has become one of the most discussed issues in international affairs.

The controversial Russian-German pipeline is generating a heated debate not only in countries where the pipeline would be passing or bypassing, but also within the entire European Union and even the United States. The dividing lines run between those states that consider the project a chance to improve Europe's energy security and those that highlight its geopolitical dimension. Germany and France have already expressed their support, underlining benefits such as the elimination of transit fees and countries. On the other hand, both the EC and Central and Eastern European (CEE) countries revealed their concerns, because Gazprom would overcome the obstacle of crossing the region, reducing the role of this area and causing a great fall in investments, especially in Ukraine. ${ }^{3}$ They also see the project as part of Moscow's 'strategic depth' policy where Kremlin achieves its political and military goals through 'nonlinear' methods, including the energy dependency. ${ }^{4}$

Fuel to the fire has been added when the US House of Representatives adopted and the president Donald Trump enacted sanctions against Russia in July 2017. The bill concludes that Russian regime uses energy exports to coerce its neighbours and has 'detrimental impact on the EU's energy security'. ${ }^{5}$ Consequently, the United States introduced punitive measures against companies (all kinds, including European ones), which contribute to the development, maintenance, modernisation or repair of energy export pipelines owned by Russia. According to analysts, in addition to joint European-Russian ventures such as Blue Stream, Sakhalin-2 liquefied natural gas (LNG) plant and Baltic LNG project, the Nord Stream 2 project will be the first to suffer. What complicates the issue is an evident fact that not only Russian interests would suffer because of the sanctions, but German, Dutch, Italian and French energy companies count their potential losses as well. As the president of Lithuania supported the sanctions, the EU Commission's statement of being 'ready to act to protect European interests' ${ }^{6}$ mirrors that deep distinction of views that exist both within the European Union and between the transatlantic partners.

\footnotetext{
2 Nord Stream (2017)

3 Beckman (2016)

4 Lasconjarias and Marrone (2016)

5 Korteweg (2017)

6 Jabri (2017)
} 
Aim of this article is to look at the issue from the perspective of the Baltic-Nordic region countries: the ones that not only may experience negative geopolitical consequences of the project, but also possess some legal and political instruments to prevent the implementation of the project. What are these instruments and what is the possibility of successfully employing them? What kind of dilemmas these countries are facing then they have to take decisions against Nord Stream-2? Moreover, therefore, what is the probability that not agreeing in principle, they will do something practically against the project?

Thus, this article is policy oriented and focuses on potential consequences that the pipeline's construction would have both on common EU energy policy and on future relations between EU MSs. The positions of supporters and opponents of the project are equally investigated. Actors are assumed to have evaluated the information at their disposal and estimated the potential costs and benefits, as well as the events' liability, in order to coherently choose the best alternative form of action. Divergent national interests and the ways in which these priorities might affect the implementation of NS2 is, therefore, one of the criteria in evaluating the overall feasibility of the project.

The analysis is based, for the major part, on previous analytical and scientific research provided by several authors - both on the NS2 issue and on security environment in the Baltic Sea region. After completing an exhaustive overview on the reasons and consequences of the pipeline's construction, the Center for Eastern studies (OSW) analysts' contributions have been used a great deal, which provided both updated statistical data and insights on the political dimension of the project. Gotkowska and Szymański offered a detailed report on Nordic region position, whilst Alan Riley of the Centre for European Policy Studies has published an essential and thorough analysis of legal and policy issues. Concerning the Baltic Sea region security environment, the works of Edward Lucas and Anne SchmidtFelzmann offered interesting and often original insight. Contributions from several institutions and think tanks, such as the Heritage Foundation and the NATO Defence College, have been used as well. The analysis of the EU's official documents and legislation remains the main method used, whilst statistical data has been retrieved from both academic articles and research papers that were consulted and from open sources, such as Eurogas, International Energy Agency (IEA) and Gasum.

\section{The Nord Stream-2 gas pipeline: how it became controversial?}

As of 2016, the biggest supplier of natural gas to the European Union was Russia, with $42 \%$ of overall imports, followed by Norway, Algeria and 
only $14 \%$ ensured by LNG. Currently, there are three main pipelines linking the European Union to Russian supplies (Figure 1):

- the route through Ukraine, supplying almost $82 \mathrm{bcm}$ in 2016, at 58\% of its capacity (142 bcm/year);

- the Nord Stream 1 pipeline, providing $55 \mathrm{bcm} / \mathrm{year}$ and used at 80\% of its capacity in 2016; and

- the Yamal-Europe pipeline, used at $100 \%$ of its capacity in 2015 and 2016, carrying $33 \mathrm{bcm} / \mathrm{year}$.

In addition to these three principal trajectories, Russian natural gas is also supplied through pipelines to Finland, the Baltics, as well as SouthEast Europe through Turkey. ${ }^{7}$ Considering all the above-mentioned, the construction of the two gas pipelines of NS2 would offer a yearly capacity of $55 \mathrm{bcm} / \mathrm{year}$, which together with the existing Nord Stream 1 would carry almost $110 \mathrm{bcm} / \mathrm{year}$, namely, more than $80 \%$ of Russian natural gas to the European Union. ${ }^{8}$ Thus, despite the struggle of the European Union to diversify its suppliers, dependency on imports of natural gas from Russia remains strong. This trend may even increase in the following years, because of the growing demand, falling domestic production and the insufficient support provided by renewables. ${ }^{9}$

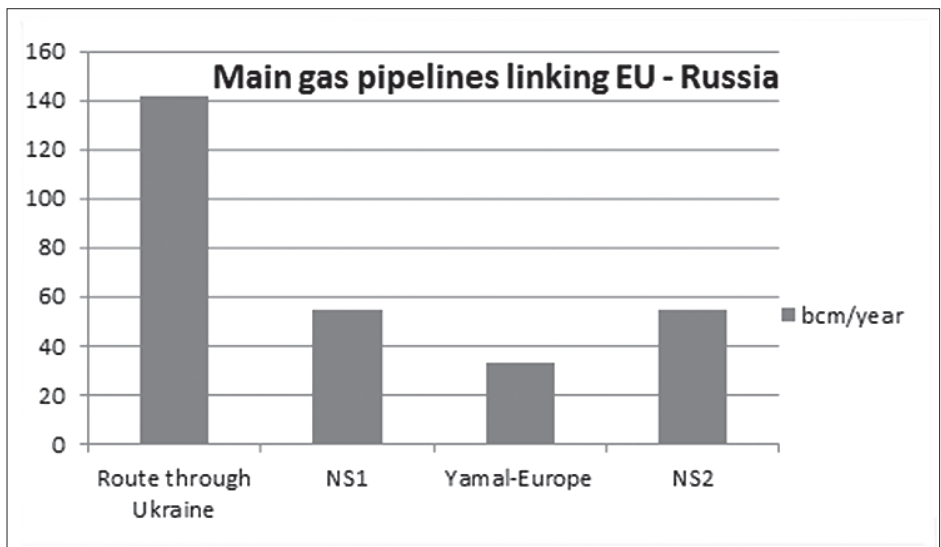

Figure 1. Main gas pipelines linking EU to Russian supplies

Gazprom underlines the fact that the imports of natural gas from Russia and Norway are almost the same, since, according to Eurogas, in 2015;

7 European Commission (2017)

8 Ibid. p. 3.

9 Ibid. p. 2. 
these countries were providing $28 \%$ and $27 \%$, respectively, of the net gas supplies for the European Union. Thus, via NS2 Russia would only offer another import route, but once natural gas is carried to Europe, the responsibility is transferred to European gas companies, which will choose amongst different suppliers, according to the best offer. ${ }^{10}$ Gazprom also provides arguments that tackle criticism provided by the sceptics of the project. They may be grouped in the following way:

1. Europe needs gas:

(a) natural gas may represent the 'best partner', considering its low emissions of $\mathrm{CO}_{2}$, in comparison to the other fossil fuels ${ }^{11}$, and

(b) the European Union urgently needs to find alternative sources of natural gas, because the domestic production is expected to decrease by $50 \%$ in the next 20 years. ${ }^{12}$

2. Environmental impact will stay minimal:

(a) offshore gas pipelines have lower environmental impact in comparison to the onshore ones, because they also require smaller amounts of energy to maintain normal levels of gas pressure and flows ${ }^{13}$, and

(b) Effects of construction will be only limited, temporary and local, as demonstrated by the first Nord Stream pipeline. ${ }^{14}$

3. NS2 will enhance the security of supply:

(a) NS2 would boost the EU's diversification strategy, because it enhances supply capacity through a separate pipeline system crossing the Baltic Sea, and

(b) because the most efficient Russian producing fields are situated in the North of the country, the Baltic Sea offers the quickest link towards the EU market.

4. Internal market will be strengthened:

(a) NS2 respects the development of the LNG system, and

(b) NS2 will boost interconnections within the EU internal market. ${ }^{15}$

5. Effect on the price will be positive

(a) NS2 will downsize the price as the new gas pipeline would boost competition resulting into cheaper prices, thanks to a wider range of suppliers ${ }^{16}$

\footnotetext{
${ }^{10}$ Nord Stream (2017)

${ }^{11}$ Ibid. p. 6.

12 Ibid. p. 4.

${ }^{13}$ Ibid. p. 7.

${ }^{14}$ Ibid., p. 18.

15 Ibid. p. 14.

${ }^{16}$ Ibid., p. 16.
} 
This is how the NS2 pipeline becomes 'flagman' for the European energy security, according to Gazprom, of course. However, the opponents provide undeniable insight that the implementation of the project would result in Gazprom's stronger influence on the EU's gas market:

1. The new gas pipeline would practically replace traditional ones, going through the Central Eastern European states (Ukraine/Slovakia transit $60-80 \mathrm{bcm} /$ year, Belarus/Poland transit $33 \mathrm{bcm} /$ year). This conclusion is based on forecasts (demonstrating decreasing demand of natural gas in Europe and possible diversification of Russian exports towards Asian markets), public announcements (about the 'unsafe' and 'expensive' transit via Ukraine) and factual final destination of the NS2 pipeline (distribution network from Greifswald reaches traditional, i.e. not new consumers);

2. Agreeing on exemptions from the EU law (see Section 3 for more details) would have severe political repercussions both on relations amongst the MSs and on the Union as a whole. Such a decision would

(a) put at risk the credibility of the European Union, because it would contradict the European Council conclusion that all new infrastructures have to comply with the Third Energy Package (TEP) rules, ${ }^{17}$ highlighting at the same time the different - and preferential - treatment reserved to NS2 in comparison to other projects.

(b) proof of how the interests of some MS are supported despite the binding legislation, whilst others are, justly, limited by the very same rules.

(c) compromise the relations between the MS as not only the project has been announced without any consultation at the EU level, but it also undermines the security of supply in the CEE countries; and

(d) further encourage the proposal of such projects with the ultimate goal to bypass the EU law and, eventually, this would sneakily erode the idea of an Energy Union as it was conceived, ${ }^{18}$ and

3. NS2 pipeline will definitely and significantly increase the overall natural gas infrastructure maintenance costs. As a consequence, national energy 'champions' will be trying to redeem investments into NS2 by maintaining at least a stable level of the natural gas consumption. This will result into the halting of the more progressive energy projects (such as development of local new type renewable technologies and LNG infrastructure) and not decreasing the dependency on the supplies from Russia.

${ }^{17}$ Goldthau (2016) p. 24.

${ }^{18}$ Riley (2016). 
The entire beauty of the dispute is the lack of clarity in the EU legislation applicable to natural gas sector. In other words, this time the European Union (differently from the case of Nord Stream 110 years ago) has reasons and instruments to halt the completion of the new gas pipeline. The next sections analyse the key aspects of this potential course of events.

\section{Are Western states on the Russian hook?}

As shown in Figure 2, the new lines would be mainly developed along the trajectory of the already existent gas pipeline, apart from the Russian sections. According to the plans, NS2 entry point will be at the Ust-Luga area in Leningrad Oblast, running through the Russian territorial waters and exclusive economic zone (EEZ). Thence, it will proceed along the Baltic Sea, crossing the EEZs of Finland and Sweden, as well as the Danish and German EEZs and territorial waters. As it was already mentioned, its exit point will be at the Greifswald area in Germany, close to the exit point of NS1. ${ }^{19}$ Not only a new pipeline $(866 \mathrm{~km})$ and three compressor stations would be built, but it is also planned to enlarge five existing compressor stations in Russia.

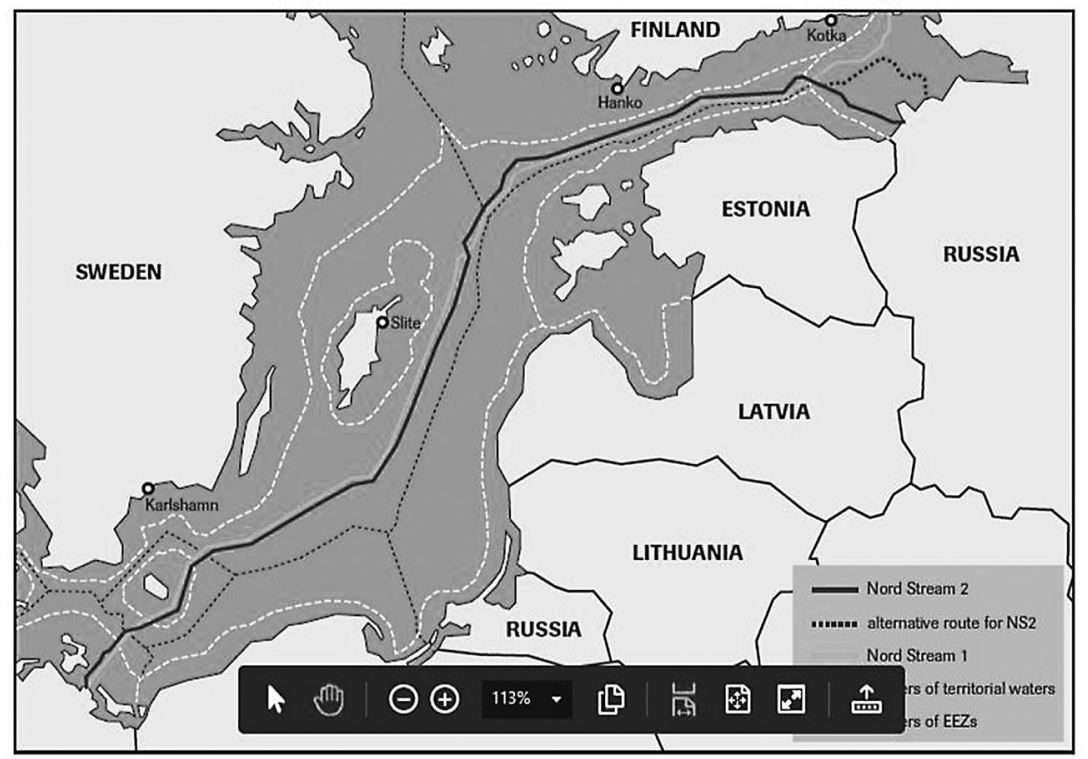

Figure 2. The Nordstream 2 pipeline

${ }^{19}$ Nord Stream (2017). 
As NS2 pipeline project requires extensive technological and financial contribution and passes western states' or international waters, the natural question is about the involvement of the western companies and governments in the project. Their attitude will influence the intensity and success of actions of host actors who clearly oppose the project.

Thus, the company responsible for the implementation of the project is Nord Stream 2 AG, a consortium based not in Moscow, but in Zug, Switzerland. More significant is the western involvement, which plays on the hand of Gazprom, such as the fact that in April 2017, Nord Stream 2 AG signed financing agreements with five Western European energy companies: Engie (France), OMV (Austria), Shell (Netherlands), Uniper (Germany) and Wintershall (Germany). According to Gazprom, the European companies will provide 950 million euros each, namely, half of the total expenses (the estimated value of which is 9.5 billion euros), for the construction of the gas pipeline. Thirty percent will be supplied with long-term funds of 285 million euros; $70 \%$ instead, amounting up to 665 million euros, will be given according to the investments of Nord Stream AG. The remaining part of expenses will be covered by Gazprom, which preserves its position as the only stakeholder of Nord Stream $2 \mathrm{AG}^{20}$

It is worth mentioning here that the original project of NS2 was with the direct ownership of some western energy giants. It had to be based on a consortium formed by Gazprom, owning only 50\% stake, and the above-mentioned European companies, with $10 \%$ stake each. The change occurred after Poland's Office of Competition and Consumer Protection expressed its concerns regarding the possible drawbacks on competition, deriving from the pre-planned division of shares. ${ }^{21}$ This way participation of European companies remained limited to financial contribution, without being unable to enter the originally planned consortium. ${ }^{22}$ This change in essence happened because of the EU anti-monopoly regulations - the ones Gazprom tries to avoid reaching the deals with national regulators and legislators in the project supporting countries.

Another aspect of western involvement and the importance of the European versus national legal framework concerns pipelines that are being used or will be built to distribute the gas across the continent after it reaches Germany. First of all, it seems that utilisation of the OPAL and NEL pipelines in Germany purely for Gazprom's needs may contradict the EU requirement of the third-party access (TPA). However, the EU institutions stay silent on the issue compromising in this way not only the EU solidarity

\footnotetext{
${ }^{20}$ Bajczuk, Kardaś and Agata Łoskot-Strachota (2017)

${ }^{21}$ Ibid.

22 Jakóbik (2016)
} 
and unity, but also very concrete implementation of the whole Third EU TEP. Despite the sanctions policy, the new pipelines are being planned for the same purpose of bringing Russian gas bypassing Ukraine. An important land branch of the new gas pipeline would be EUGAL (with a maximum of $51 \mathrm{bcm} /$ year), crossing Germany, in parallel to the already existent OPAL. ${ }^{23}$ If implemented, GASCADE would strengthen its position in the German market, as well as its control of the gas infrastructure in the East of the country. Europe becomes a hostage of its own greedy and uncoordinated policy where the application of double standards is a norm.

\section{Legal and political arguments to halt the project}

The planning and construction process of NS2 is conducted under the provisions of the United Nation Convention on the Law of the Sea (UNCLOS) and the Espoo Convention. ${ }^{24}$ According to these, countries enjoy regulatory prerogatives with respect to pipelines laid in their EEZs. In the event that pipelines are laid in their EEZs and/or on the continental shelf, states have the right to delineate the course and/or set out the terms for the laying of the pipelines and exercise jurisdiction over them.

In addition to that, the EU Treaties and the relevant secondary EU laws extend to the EEZ of the EU MS. First of all, the provisions of the TEP and the legal acts associated with the EU Energy Union, which was launched in February 2015 and became one of the 10 priorities of the Junker's Commission. No provision of TEP includes argument to support the point that the NS2 gas pipeline, in its part located in the territory of the European Union, is not subject to the provisions of TEP. On the contrary, provisions of TEP contain a number of regulations and provisions supporting the fact that transmission gas pipelines are fully subject to the regulatory requirements provided for in the TEP in the territory of the European Union. No exemption in this regard is foreseen for the transmission pipelines connecting an MS with a Third Country.

Thus, in principal, there are no objections that domestic law and the EU law are fully applicable to the extension of NS2 entering the territorial

${ }^{23}$ EUGAL, similar to OPAL and NEL, is a product of GASCADE, a joint venture between Gazprom and BASF/Wintershall (Germany). The new line is expected to carry gas from the trans-Baltic route to the South and West of Germany and to Central Europe, Ukraine, the Balkans and Italy as soon as in 2019. On the other hand, there are still many controversial aspects linked to its construction. First of all, the actual cost of the project has not been specified yet; secondly, as for OPAL, GASCADE would encounter the restrictions imposed by the EU legislation on TPA, which could reduce its capacity by 50\% (Łoskot-Strachota and Popławski (2016).

${ }^{24}$ Lang and Westphal (2017). 
waters of Denmark and Germany. However, sceptics say that problems arise with regard to its applicability on the offshore part, which runs through the EEZs of two EU MSs. According to the UNCLOS, the jurisdiction of the coastal state (and, therefore, of the Union) on pipelines and cables laid on its EEZ seems to be limited to the protection of its rights of exploration of the seabed and exploitation of natural resources, as well as to the control of pollution that could derive from the construction process. ${ }^{25}$

However, in the light of the new EU legislation and considering the objectives of the Energy Union, application of the legal regime to the offshore part of NS2 becomes fundamental. Opponents of the project highlight its inconsistence with the TEP provisions and thus with the objectives of a resilient Energy Union, claiming EU law applicability to the subsea strings of NS2. This seems to be supported by law precedents that stated the necessity of applying the EU legislation beyond the territorial waters of the MSs in order to be fully effective.

In this case, the inconsistency of the three key $^{26}$ provisions of the 2009 Directive would be clear - namely, ownership unbundling, TPA and tariff regulations. ${ }^{27}$ Particularly striking is the incompatibility of NS2 with the ownership unbundling provision, because Gazprom would be the sole shareholder of the project, being at the same time producer and supplier of natural gas. ${ }^{28}$

Moreover, the uniformity in the application of liberalisation rules prescribed by the TEP should be considered as an argument reinforcing the extension of the EU law to the offshore part of NS2. ${ }^{29}$ On the contrary, its partial application would ultimately compromise the functioning of a single energy market and the objectives of the energy triangle. Whilst it would be possible to require an exemption from the provisions under Article 36 of the 2009 Directive, it ultimately does not seem to be a viable solution for the Nord Stream 2 AG, because the project would have to comply with precise objectives that the NS2 is unlikely to be fulfilled. ${ }^{30}$ By contrast, it

${ }^{25}$ Riley (2016).

${ }^{26}$ Ibid., pp. 19, 20.

27 Ibid., pp. 10, 11.

${ }^{28}$ Bajczuk, Kardaś and A. Łoskot-Strachota (2017)

${ }^{29}$ Riley (2016)

${ }^{30}$ Directive 2009/73/EC provides the possibility to require an exemption from its provisions under Article 36, which can be obtained if the project respects certain conditions. Amongst these, it must enhance the competition in gas supply, the security of supply and being not detrimental for the functioning of the internal gas market. Given the different interpretations the MSs have with regard to Gazprom's role and the consequences of the project, it is unlikely that the Nord Stream 2 AG will apply for and obtain such an exemption. See Riley (2016), pp. 13 
has been argued that the EEZs remain governed by the UNCLOS, because of both the paltry law precedents and the track record of past exemptions or non-application of the EU regulation to gas infrastructure. ${ }^{31}$ Although, for instance, it is true that the first string of NS1 became operative when the TEP provisions had already been required to be implemented into national law, this cannot be considered as a precedent of immunity, especially in the light of the measures taken towards other projects because of inconsistency with the above-mentioned requirements, such as the South Stream and the Yamal pipelines. ${ }^{32}$

Another factor that seems to be decisive for the application of the TEP provisions is the categorisation of the pipeline system. Gazprom classified the NS2 as an import pipeline, drawing examples from existing infrastructures, namely, the NS1 and pipelines from Northern Africa to Spain and France, which do not fall under EU's internal gas market laws. ${ }^{33}$ However, not only the category of import pipeline is non-existent, but also the Northern Africa pipelines are actually examples of upstream pipelines, because they connect gas fields to the European network. ${ }^{34}$ Whilst, in this case, exemptions from the TEP provisions are contemplated, this is not the case for transmission pipelines, the category under which almost certainly would fall both NS1 and NS2 because they connect the Russian Unified Gas System with the German gas network. ${ }^{35}$

In the light of these problems and in response to calls of some EU MSs to assess the project, the EC affirmed the inconsistency of NS2 with the objectives of the Energy Union, confirming at the same time the ambiguity of the legal framework that should regulate offshore pipelines. It also confirmed the impossibility to operate in a legal void, as well as under the sole legislation of a third country. However, what it asks for is formulation of a specific regulatory regime to agree with Russia, respecting the fundamental principles of international and EU energy law and the objectives at the basis of the Energy Union. Therefore, the EC highlights the necessity to obtain a mandate from the Council in order to negotiate with the Russian Federation a specific legal regime for the offshore part of NS2. ${ }^{36}$ The potential agreement would take into account fundamental principles of the EU energy law and international law.

\footnotetext{
${ }^{31}$ Goldthau (2016)

${ }^{32}$ Riley (2016)

${ }^{33}$ Nord Stream (2017).

${ }^{34}$ Lang and Westphal (2017)

${ }^{35}$ Riley (2016)

${ }^{36}$ Łoskot-Strachota, Kardaś and Szymański (2017)
} 
However, the authorisation for a mandate to entail negotiations would require a qualified majority of the MSs' votes, which have very different visions of what the mandate should contain, given their divergent opinions both on Gazprom's reliability and on the consequences of the project. The danger is to have a weak mandate, which would lead to negotiations on general principles of the EU energy law without considering the TEP in its essence. Indeed, the EC seems to contemplate the possibility to avoid the imposition of the requirement of complete ownership unbundling, whilst it is unclear to what extent the TPA rule would be applied. ${ }^{37}$ Moreover, in its Recommendation to the Council, it requires the agreement to mitigate potential negative impacts on other states, referring mainly to the damage the project would cause to the CEE countries' efforts to diversify and secure their gas supplies, as well as to the transit status of Ukraine. ${ }^{38}$ It remains unclear how massive the potential negative impacts on one or more MSs have to be in order to halt the project.

\section{View from the Member States}

In the light of discussions that started within the EU institutions, the MSs remain strongly divided on the issue. As Poland, the Baltic and, partially, Nordic States, as well as Ukraine, oppose the project, it seems that Slovakia may be considering it positively, in order to prolong the current advantages that are derived from gas transit after 2025 (Groszkowsk \& Łoskot-Strachota, 2016). However, a final decision on the approval to build NS2 will depend on the authorities of those countries crossed by the new pipeline, namely, Finland, Sweden, Denmark and Germany. The position of the Nordic region is of strategic importance for Baltic security as the Swedish Gotland Island is one of the geographic spots that would be fundamental in case of a crisis or conflict between NATO and Russia. ${ }^{39}$ The next sections will present more details on this.

\section{Complicated choice for Denmark}

As the planned route would go not only via the economic zones of Finland and Sweden, but also via $139 \mathrm{~km}$ of Danish territorial waters, there is widespread hope for Denmark's refusal based on the Convention on the Law of the Sea, which would cause a deviation in the line. In addition, the laying of the pipeline could be impeded considering that to the North of

\footnotetext{
${ }^{37}$ Łoskot-Strachota (2017)

${ }^{38}$ European Commission (2017)

${ }^{39}$ Coffey and Kochis (2016)
} 
the island of Bornholm; there is an important shipping route that crosses the Danish and Swedish EEZs. To the South, instead, legal controversies could slow down the process of construction, because the Polish and Danish EEZs are not clearly defined ${ }^{40}$ As a proof of the sceptical Danish approach, the foreign minister of Denmark joined his Lithuanian colleague whilst criticising the plans of NS2 expansion in September 2017, asking the EC to be stricter in connection to the project. ${ }^{41}$

In addition to that, a new Danish law could make it possible to block pipelines that run through Danish territorial waters by reference to security concerns. ${ }^{42}$ In October 2017, Danish parliament started the discussion of the bill that would widen the scope of arguments taken into account whilst discussing the applications for pipelines that use Danish territorial waters. According to the new law, in addition to the environmental concerns, the country would take into account security, foreign policy, defence and political concerns before granting approval. As Nick Haekkerup, a spokesman for the opposition Social Democrat party stressed, 'in a situation where the Russians are acting aggressively and where Danish soldiers are about to be stationed in the Baltic countries in order to balance the situation, we have to weigh in how it [Nord Stream 2] fits our foreign policy interests'. ${ }^{43}$ According to the press, the law could enter into force in January 2018, but it remains uncertain whether that would be quick enough to block a pending application by the builders of Russia's Nord Stream 2 gas pipeline. ${ }^{44}$

However, historically, the issue in Denmark has been treated only sporadically, because it causes controversial dilemmas. The country is trying to avoid a direct confrontation with the actors implied in the project: Germany, which is its main economic partner and supports NS2 and the United States and CEE countries, opposes it and represents Denmark's principal allies in security policy. Moreover, according to the Law of the Sea, not only should Denmark allow the construction of the new gas pipeline in its territorial waters, but it also has the difficult task of avoiding the overlapping of Danish and Russian interests in the Arctic. Denmark's position on NS2 is even more complicated, because of the approval given to the previous NS1, in a moment in which domestic production was diminishing. On the other hand, Danish minister of energy Lars Christian

\footnotetext{
${ }^{40}$ Gotkowska and Szymański (2016)

${ }^{41}$ BNS (2017)

${ }^{42}$ Kirk and Rettman (2017)

43 Ibid.

${ }^{44}$ Ibid.
} 
Lilleholt once noted that 'times change', referring to Russia's increasingly aggressive behaviour in the past 3 years ${ }^{45}$.

Nowadays, Denmark is independent in the energy field, because it even exports both oil and natural gas and is striving to shift to renewables by 2050 , which gives huge advantages to the country's decision on NS2. ${ }^{46}$ As a consequence, there is no surprise that majority of political actors in fact support its construction, whilst only some leftists politicians, especially Social Liberal and Social Democrats, are against it. Thus, in reality, strong appeal to national law or the Law of the Sea to halt the project is hardly expected. As it has been noted by the former NATO secretary general Anders Fogh Rasmussen, Denmark could say no to a pipeline that goes through Danish waters, but in that case, Gazprom could just move the route into international waters. ${ }^{47}$ This clearly reflects general notion in Denmark: real opposition to the project must come not from the individual states but the European Union as whole.

\section{Hopes on Sweden}

The Swedish debate on NS2 is influenced by both the country's energy situation and broader security challenges in the Baltic Sea region. Swedish imports of Russian gas are negligible, even though they would probably increase because of the Danish Tyra gas field's closure announced in $2016 .{ }^{48}$ Notwithstanding, Sweden is strengthening its energy relations with Norway, whose imports of LNG are likely to increase after a second LNG terminal started operating in 2014. Moreover, just $10 \%$ of its national electricity production comes from fossil fuels, whilst the government set out the goal to achieve an energy mix made up of $100 \%$ renewable energy by $2040 .{ }^{49}$ Sweden energy policy is, therefore, much more aligned with the shared objectives agreed at the EU level in comparison with other MSs, making the country one of the strongest supporters of the EU's energy market liberalisation process and of a true Energy Union.

Given the less impact, the project could have on its own supply situation, soft and hard security consequences have a greater relevance on the Swedish debate on the NS2 pipeline. The company, whose major shareholder is the Russian state-owned Gazprom, plans to use the harbour and storage facilities of Karlshamn in Blekinge and Slite on Gotland Island, thus allowing them to play a role in the logistic plans for the construction

\footnotetext{
45 Ibid.

${ }^{46}$ Gotkowska and Szymański (2016)

${ }^{47}$ Kirk and Rettman (2017)

${ }^{48}$ Schmidt-Felzmann (2016)

${ }^{49}$ Ibid., p. 79.
} 
project. $^{50}$ Whilst this would bring economic benefits for the local authorities, the possible use of the Swedish ports by Nord Stream 2 AG is a source of concern, as being present in the ports; Russia has a possibility, which may lead to sabotage activities. ${ }^{51}$ Swedish military experts also highlighted the risk of the presence of Russian navy in Swedish economic zone as a way to control the pipeline. Could these arguments serve for the purpose of blocking the construction of the NS2?

Starting with the Karlshamn, the port is located in a geographic area of strategic importance for the Swedish Armed Forces, because it is situated close to the Swedish Navy's main base in Karlskrona. On the other hand, the decision of renting Slite harbour on Gotland Island, which has been recently re-militarised, received the negative opinion of military experts and the Supreme Commander of the Swedish Armed Forces himself, who warned the decision-makers about the risks of allowing Gazprom to operate on Swedish soil. ${ }^{52}$ Swedish military are concerned that Russia is extending its Anti-Access/Area-Denial (A2/AD) capabilities. ${ }^{53}$ In this context, the accessibility to Gotland Island is of critical importance in order to reinforce the Baltic allies and overcome Russian A2/AD strategy. By contrast, if Gotland were to be seized by the Russian forces, there would be no possibility for NATO to intervene in the Baltic States. It can be only noticed that Gotland area is the key for the construction, operation and safeguarding of the NS2 as well. ${ }^{54}$

Indeed, Russia is intensifying its aggressive espionage activities against the Swedish Armed Forces, making it clear that Sweden's territory is already under heavy surveillance for military strategic purposes. As, for instance, a massive increase of reports about Russian officers posing as 'tourists' has been registered on the island of Gotland, whilst reports on such activities have increased after the Supreme Commander's decision to deploy in advance a mechanised company on the island. ${ }^{55}$ The number of Russian military provocations against Sweden has also increased in the recent years, whilst deliberate interferences of the military vessel of the Russian Baltic Fleet disrupted several times the laying of the NordBalt cable, the electrical interconnector built between Lithuania and

${ }^{50}$ Gotkowska and Szymański, p.3.

51 Ibid.

52 Ibid.

53 The basic idea of A2/AD is preventing and interdicting the adversary from deploying its forces into the theatre of conflict, minimizing its room of maneuver at the operational level.

${ }^{54}$ Lasconjarias and Marrone (2016)

55 Schmidt-Felzmann (2016) pp. 84. 
Sweden, showing the intention to hamper the integration of the Baltic energy market. ${ }^{56}$ Renting of Karlshamn and Slite ports is likely to further increase Russia's intelligence gathering capabilities and facilitate additional sabotage activities because of the ports' strategic location.

Overall, Sweden's opposition to the NS2 seems to have been reinforced after a visit of the US Vice President Joe Biden in August 2016. Swedish scepticism on the project is linked to the fact that the domestic consumption of natural gas is very low (around $4 \%$ ), with $20 \%$ of demand covered by national production and the remaining $80 \%$ by imports from Denmark. However, the government today is especially concerned about the real nature of the project, perceived as an instrument to increase Russia's economic position and political influence in Europe and to justify military operations in the Baltics as a way to protect the gas infrastructure. However, unable to appeal to the national legislation, the country looks at the EU intervention, based on its energy and climate policy and security interests. Swedish politicians are also ready to cooperate with Baltic countries on the political level to oppose NS2.

\section{Finland: approval expected}

Overall, the Finnish attitude towards the new project may be defined in terms of neutrality, as it happened for the construction of NS1. Indeed, the first project was conducted by the Russian-Finnish company North Transgas (later Nord Steam company), which, in 2005, became totally owned by Gazprom, because Fortum decided to sell its 50\% stake. Nowadays, Finland look at Gazprom as a reliable partner for many reasons: first of all, it has not experienced the same interruptions of provision as in the case of CEEs; second, there are strong ties between domestic companies and Gazprom, which has also recently bought $25 \%$ stake in Gasum; moreover, natural gas represented only $7 \%$ of the total national energy consumption in 2015 . In addition to that, Finland is working on the development of LNG terminals, as well as of a pipeline connection with Estonia. Consequently, no threats to security are perceived in relation to the project and on the contrary, according to some interest groups, the Finnish economy will receive many advantages, such as the creation of new job positions. ${ }^{57}$

The main obstacle for the implementation of the NS2 project in Finland is national EIA procedure that is fundamental to address the widespread environmental concerns of Finland. However, the EIA report showed that most of the impacts will be local and short term and mainly linked to the

\footnotetext{
${ }^{56}$ Lucas (2015) pp. 10

${ }^{57}$ Gotkowska and Szymański (2016)
} 
construction phase.$^{58}$ EIA for Finland also noticed that the enlargement of the NS2 is a necessary action to cover the supply gaps expected in the EU28 by 2020, because of several concomitant factors: the projected decline in domestic production of the European Union is from $131 \mathrm{bcm}$ in 2020 to $97 \mathrm{bcm}$ in 2030 to $66 \mathrm{bcm}$ in 2050. Thus, from this point of view, Finland's approval to NS2 is largely expected, although the formal procedure still requires some other necessary phases, including Government Consent for the use of the Finnish EEZ (the exploitation right) and the permit for pipeline construction and operation according to the Water Act. ${ }^{59}$

Within the context of energy security, Finland seems to be a supporter of NS2 as well, although this could mean a greater dependency on Gazprom, which is already the only supplier of natural gas to the country, because of the lack of a well-developed transmission system. Yet, Finland has been working on the diversification of its energy supplies in the past few years, which translated into a growth of $38.7 \%$ of total final energy consumption by the end of 2014 (it was just 29.2\% in 2005), with biofuels and hydropower as leading sectors. Moreover, an LNG import terminal was opened in Pori in September 2016 by Gasum, the construction of the Tornio Manga LNG project should be completed in $2018 .{ }^{60}$ In addition, in 2016, the Finnish government managed to complete the renationalisation of gas utilities, thanks to the acquisition of $25 \%$ share of Gasum by Gazprom.

Summing up, Finland's attitude mainly depends on Finnish politicians' fear of a confrontation with Russia. In January 2016, a meeting between D. Medved and J. Sipila confirmed the willingness of both countries to rebuild their political relations. ${ }^{61}$ Such a reality may be interpreted as a direct consequence of the so-called 'Finlandisation', namely, the attempt of the country to maintain good relations with its neighbour, making some concessions. Differently from many Eastern European countries, Finland did not experience a process of 'lustration', which contributed to Moscow's prolonged influence on Finnish politics during the years of the Cold War. Such a condition has been partially inherited until now, as it emerges from the opposition to Finland's access to NATO and from the strong economic ties existing between the two states. ${ }^{62}$ Moreover, Finnish authorities clearly wish to strengthen economic ties with Russia. ${ }^{63}$

\footnotetext{
${ }^{58}$ Nord Stream (2017).

${ }^{59}$ Ibid.

${ }^{60}$ Gasum (2016).

${ }^{61}$ Jakóbik (2016).

62 Shandra and Virkki (2016)

${ }^{63}$ Gotkowska and Szymański (2017)
} 


\section{Germany's position: business prevails}

Whilst a heated debate continues to animate the whole Europe, Germany and Austria have not abandon their hopes to exploit NS2 in order to enhance their competitiveness in comparison to other European gas suppliers and obtain a new link to the Siberian fields, where they are stakeholders. The German position has been clearly expressed from the beginning: both the government and many CEOs of influential energy companies have treated NS2 as a business project, strongly supporting its implementation, considered beneficial to the national economy.

Indeed, Germany claims that the new pipeline will neither harm Ukraine nor threaten the security of supply in Central Europe. Yet, it is still unclear how this will be possible, considering the necessary transfer of significant amounts of resources to NS2, as well as the expected redirection of flows from Ukraine to new pipelines set in Germany. Furthermore, German authorities affirmed that the new pipeline should not be subject to the TEP, because it will cross the EEZ of some MSs, which should only be responsible for the concession of the permit to construct. Whilst Angela Merkel has not officially opposed the project, the deputy Chancellor and Economy Minister Sigmar Gabriel (SPD) promised that the EC would not impede the successful realisation of the project. The federal government seems to ignore the weak voices of those opposing it, such as members of the Christian Democratic Party and the Greens, which underlined the incompatibility with the country's aims to reduce $\mathrm{CO}_{2}$ emissions and shift to renewables. ${ }^{64}$

In addition to the federal government, for the regional governments of Baden-Wurttemberg, Bavaria and North Rhine-Westphalia, the construction of the new gas pipeline would strengthen national energy security, offering a cheaper alternative to the use of LNG terminals in Benelux and France. Mario Mehren, CEO of Wintershall, claimed the necessity to fully use the OPAL gas pipeline to ensure the provision of natural gas to the South of Germany. Indeed, the planned closure of all German nuclear power plants is forecasted to induce a deficit of power of $4 \mathrm{GW}$, considering the government's provision of an increase in the gas share in the domestic energy mix (from $8.9 \%$ in 2016 to $23 \%$ in 2025). For this reason, Axel Botzenhardt, the CEO of Thyssengas, is in favour of a closer cooperation with Gazprom and wishes to enlarge the quantity of natural gas imported from Russia, through NS2, building a $100-\mathrm{km}$ route, connecting Lower Saxony to North-Rhine-Westphalia. Yet, if analysed on a deeper level, rather than boosting domestic energy security, NS2 will simply provide additional

${ }^{64}$ Łoskot-Strachota (2017) 
income, thanks to the transit and trade of natural gas produced in Central Europe and Ukraine. ${ }^{65}$

\section{Ambiguous 'New Europe'}

Then it comes to the so-called 'new European' states, first of all, the leaders of Slovakia, Poland and other CEE countries publically approach the NS2 project in the light of political implications. In this regard, they stay mostly united and jointly oppose the project noticing the need to apply provisions of the TEP to the offshore and onshore sections of the Nord Stream 2, as well negative implications of the project on Ukraine, the unity of the European Union and all other conventional arguments. Eight EU governments signing a letter objecting to the NS2 in March 2016 is a good proof of this: the president of Lithuania, the prime ministers of the Czech Republic, Estonia, Hungary, Latvia, Poland, Slovakia and Romania addressed to EC President Jean-Claude Juncker with the worry that NS2 would generate 'potentially destabilizing geopolitical consequences' ${ }^{66}$

However, economic arguments are weighted in a different way, which results into divergent and contradictory attitudes of some CEE MSs, which sometimes act 'pragmatically' and do not hide a partial willingness to cooperate with Gazprom. Slovakia, for instance, was one of the signatories of the joint letter of complaint to the EC, whilst its representatives never hold back with criticism towards Berlin and Gazprom. However, it could not be ruled out that Bratislava would eventually give its approval to the construction of NS2 in case gas transit will be ensured. First, Eustream - the national transmission operator - currently has a long-term contract with Gazprom that requires an annual transport of $50 \mathrm{bcm}$ until 2028, suggesting that eventual losses because of the NS2 would not be excessive. Second, Russian assurance of maintaining the Czech and Slovak gas pipeline system, as well as some transit from Ukraine to Slovakia after the implementation of NS2, was welcomed by Bratislava. Considering all the above-mentioned, it is possible that Slovakia could abandon its initial criticism in order to safeguard both its national economic interests and the interests of Eustream transmission operator. ${ }^{67}$

Equally, the assurance of at least the partial maintenance of the Ukrainian gas route is in the interests of Czech Republic. However, it is worth noting that the country is already connected to NS1 system, because the Gazela pipeline linking Saxony to Bavaria allows gas transit from the OPAL pipeline, which would be one of the principal distributors of Russian

\footnotetext{
65 Popławski (2016).

${ }^{66}$ Sytas (2016)

${ }^{67}$ Groszkowski and Łoskot-Strachota (2016)
} 
gas across the continent, after having reached Greifswald. ${ }^{68}$ Thus, overall, NS2 potentially offers Czech Republic a chance to expand its position as a transit country through reverse flows, a factor that is undoubtedly taken into consideration by Prague despite its reservations on NS2 political implications.

Poland, by contrast, is much more concerned about the possibility that the pipeline project would ultimately jeopardise the existence of the Yamal route distributing Russian gas to the western markets. Whilst the country effectively worked on improving its security of supply, economic and logistical drawbacks, related to the profitability of its LNG terminal, as well as the damage NS2 would cause to the development of shipping, play an important role in shaping its objections. More important, Warsaw emphasises the geopolitical and foreign policy implications the project would have for the entire eastern region, thus aligning itself in a much more resolute way to the Baltic States' positions.

Seemingly, in Romania, foreign policy considerations play a decisive role as well. Although the implementation of NS2 could have repercussions for planned pipelines involving Romanian firms, the country's imports of Russian gas are negligible, whilst its gas market is much more dependent on the fate of projects such as TurkStream or South Stream. Thus, Bucharest traditional suspicion towards Moscow's intention and its support for the Ukrainian cause are the main reasons behind its objections to the RussianGerman pipeline.

This logic, however, cannot be applied in the case of Hungary. Despite the potential blockade of the Ukrainian route, which would imply a reconfiguration of its supply channels, Budapest could benefit from the creation of additional interconnections with Slovakia because of NS2 implementation. Consequently, Hungary is very much likely to adopt a pragmatic approach towards the project, because geostrategic and foreign policy arguments have less prominence in its calculations. ${ }^{69}$

Overall, the option of joining the Russian side may not seem so much unlikely for countries such as Slovakia or Hungary, which differently from Baltic States would not face consistent political and geostrategic consequences. Gazprom's proposals of cooperation, together with hesitation and slowness of the European Union in reacting against Russian initiatives, may therefore lead certain CEE states to opt for the implementation of the project in order to minimise the already calculated disadvantages and find a good compromise to balance their gain-to-loss ratio.

\footnotetext{
${ }^{68}$ Lang and Westphal (2017)

${ }^{69}$ Ibid.
} 


\section{Quo vadis, Europe?}

Although it was expected that by the end of autumn 2017, the European Council would take decision on the issue, the MSs will definitely need additional months to elaborate the final version of the mandate. ${ }^{70}$ How the situation could elaborate both, what regards the Commissions mandate to negotiate and the entire NS2 project in general?

It cannot be ruled out that Gazprom will manage to influence MSs' decision by proposing profitable offers of cooperation, which could persuade them that the best solution is focusing on minimising their losses. ${ }^{71}$ This is especially the case for those countries where foreign policy consequences and geostrategic considerations are less prominent than in the Baltic States or Poland, for instance, in Slovakia or Hungary. ${ }^{72}$ On the other hand, the Nordic countries, which have legally no possibility to halt the project, have already adopted a very diplomatic stance. The interest in having the UNCLOS applied (Denmark) or a track record of good relations with Gazprom (Finland) led them to refrain from unambiguously backing either the supporters or the opponents of the project. Sweden, by contrast, took a more firm position on the issue, highlighting the threats NS2 would pose to its national security and declaring its willingness to cooperate with the Baltic States in order to oppose it at the EU level. However, it is difficult to see how it would align itself against the large EU MSs to block a project that has practically no repercussion on its own supply situation. ${ }^{73}$

Overall, given the efforts the Nordic countries have made in encouraging the EC to take a more active approach on the matter, they are likely to favour any type of mandate, regardless of its content. Therefore, one possible outcome would be the achievement of a mandate in the forms envisaged by the EC in its Recommendation to the Council, which would result in the application of two different legislations for the two different parts of the pipeline system. Although Moscow still hopes that Brussels will finally confirm that the EU energy law is not applicable to the offshore part of NS2 - offering most probably in return its readiness to continue some gas transit via Ukraine after $2019^{74}$ - the establishment of an ad hoc legal regime could be viewed as a not-so-bad solution, because a weaker regulation would equally serve the interests of the project's supporters.

By contrast, if a mandate would not be authorised because of irreconcilable divergences on what it should contain, the long-term outcomes

\footnotetext{
70 Łoskot-Strachota (2017)

${ }^{71}$ Groszkowski and Łoskot-Strachota (2016)

${ }^{72}$ Lang and Westphal (2017)

${ }^{73}$ Gotkowska and Szymański (2017)

${ }^{74}$ Łoskot-Strachota, Kardaś and Szymański (2017)
} 
would eventually depend on which kind of actions the EC would pursue thereafter. As it stated the impossibility to operate in a legal void, as well as under the law of a third country, without obtaining a mandate, the project is unlikely to be implemented in the short term. In this context, a possibility could be to refer the problem back to the EC's lawyers, who would work to overcome the legal ambiguity and who most probably will find good reasons to extend the EU energy law to offshore pipelines. This would serve the interests of a truly interconnected and liberalised European internal gas market, which is the most effective way to ensure the implementation of the Energy Union's goals. Although it has been highlighted that the objectives of the Energy Union are weighted in different ways by each MS, whilst the implementation of the TEP also diverges considerably from country to country, ${ }^{75}$ this could become the occasion to work to at least partially harmonise contrasting trends. In a broader perspective, this approach could also incentivise the assessment of pipeline systems that, nowadays, are not in line with the requirement of the TEP, namely, the NS $1,{ }^{76}$ helping to overcome the harmful criticism of 'double standards' in evaluating energy projects.

As it was noted by the EU commissioner for competition Margrethe Vestager in Vilnius October 2017, the European Union has no legal recourse to stop NS2 being built. Referring to a Commission's proposal to negotiate a NS2 legal model with Russia on behalf of the European Union, she saw a possibility to ensure that the pipeline did not operate in a 'legal void'. According to her, that would ensure pipeline does not harm EU energy interests. However, Council's legal service said that the Commission had no mandate to do even that and that Germany would be free to veto such an agreement in any case. ${ }^{77}$ Thus, if blocking the project fails, it will mean simply postponement of an issue that is expected to recur in the future, possibly in even more deceitful forms. Considering the timing NS2 has been proposed - just few months after the EC declared the Energy Union as one of its 10 priorities $^{78}$ - politically motivated initiatives, perhaps in a renewed international security environment, are likely to call into question the credibility of the European energy policy and its long-term objectives, with all the negative consequences this would entail.

\footnotetext{
${ }^{75}$ Lang and Westphal (2017)

${ }^{76}$ Riley (2016)

${ }^{77}$ Kirk and Rettman (2017)

${ }^{78}$ Lang and Westphal (2017), pp. 26.
} 


\section{Conclusions}

In the light of the renewed Russian assertiveness towards its neighbours, the security in the Baltic Sea region has to be considered from a broader perspective. In this context, the diversion of supply from Ukraine to NS2 would cause the CEE states not only the loss of their role as transit countries, but it is likely to undermine the profitability of new diversification projects (in Poland and the Baltic States) ${ }^{79}$ with the risk of jeopardising their integration efforts into the western European gas market and rolling them back to a condition of higher Russian leverage in their energy markets and greater supply risk. ${ }^{80}$ Consequently, the most vulnerable countries in this context try to postpone or terminate the implementation of the NS2 pipeline and expect understanding from the more powerful actors of the international relations.

Probably the easiest way to stop the project would be the EU's Commission assessment of its incompatibility with the TEP, which is what some EU MSs are trying to obtain. However, the EC is asking the Council to start the negotiation process with Russia. It urges for a new regulatory framework to apply to the new gas pipeline, taking into account the fundamental principles of the EU energy law and international law, such as transparency of the operations of the gas pipeline, non-discriminatory tariffs, equal opportunities to all third parties to access the pipeline and separation of the activities of supply and transport. ${ }^{81}$

The EU MSs have different feelings about the Commission's attempts to receive the mandate for negotiations with Russia about this necessary legal framework. It is because the Commission takes a double stand in regard to relations with Gazprom: on the one hand, it says that the new gas pipeline would not support the EU's main objectives of diversification of sources, routes and suppliers; on the other hand, it wishes to have a meeting with Russian authorities as soon as possible in order to negotiate legal framework for pipeline's operation. In any case, if the project would be stopped by unified action, it will demonstrate that the Union strives to resolve geopolitical challenges through consultation and solidarity, taking into considerations the interests of all its members and remaining at the same time coherent with its declared principles. Nevertheless, most of the MSs and other actors support the creation of specific legislation for NS2, instead of conceding a mandate to the Commission. This is the position expressed by Nord Stream 2 AG, Gazprom, Germany and six European

\footnotetext{
${ }^{79}$ Lang and Westphal (2017), pp. 29

${ }^{80}$ Riley (2016) pp. 12.

${ }^{81}$ European Commission (2017)
} 
transport system operators (Gas Connect in Austria, Net4Gas in Czech Republic, Fluxys, Gascade, Gasunie and ONTRAS in Germany).

Germany's position in essence is clear: Chancellor Angela Merkel treats the project as having a commercial nature, refusing any discussion referring to the political dimension. ${ }^{82}$ However, Nordic countries find themselves in a more controversial situation. Amongst the opponents of NS2, there is widespread hope for Denmark's refusal, as it has very concrete instruments for doing it. Finland and Sweden instead seem to lack the same possibilities to delay the construction of NS2. The only chance they have in order to take time to wait for the Commission's intervention is the assessment of the environmental impact of NS2. Lacking the ability to overcome its dependency on Russian natural gas, at least in the short term, Finland is trying to avoid the politicisation of the NS2 issue. ${ }^{83}$ With the expansion of its LNG terminals and the construction of a pipeline connection to Estonia, the Finish approach may become more sceptical.

Despite lacking the legal grounds for halting the project, Sweden could prolong the process at least in the short term, because its formal permission is required. However, Swedish government clearly tries to prevent the aggravation of the existing defence vulnerabilities vis-à-vis Russia. On the other hand, despite the economic benefits for Gotland, local authorities agreeing to increase the amount of Russian investments on the island would enhance the Russian influence in the region. Moscow could also use the NS2 as an excuse to expand its military presence in the Baltic Sea under the guise of works related to laying the gas pipeline and to the protection of gas infrastructures. Hence, what is at least expected from Sweden is that the country will improve the communication with both the local authorities and the EU MSs, in order to assure that 'commercial deals' that negatively affects national security would not be assessed only on their commercial basis.

Thus, on the one hand, there is a certain wish of the Nordic countries (strongly supported by the United States, CEEs and domestic opposition parties), to distance themselves from Russia, considering the recent tensions in Ukraine and the increasing security concerns in the Baltics. On the other hand, halting the implementation of NS2 would mean going against Germany, which is a strong supporter of the pipeline. Consequently, rather than taking a clear decision, they expect the EU Commission to prove the compatibility of the project with the TEP ${ }^{84}$ Yet, the EU's hesitation in taking some measures to counteract the Russian side

\footnotetext{
${ }^{82}$ Łoskot-Strachota (2017).

${ }^{83}$ Gotkowska and Szymański (2016)

${ }^{84}$ Ibid.
} 
Humanities and Social Sciences: Latvia (Volume 26(2))

may result in a change of attitude of some MSs towards the approval of the project, as a way to minimise eventual losses deriving from the expected implementation of the project.

\section{REFERENCES}

Bajczuk, R., Kardaś, S., Łoskot-Strachota, A. The Nord Stream 2 financing agreements, Centre for Eastern Studies. https:/www.osw.waw.pl/en/publikacje/analyses/ 2017-04-26/nord-stream-2-financing-agreements (accessed on 26 April 2017).

Beckman, K. New study: Nord Stream 2 will benefit security of gas supply in Europe. Energy Post. http://energypost.eu/new-study-nord-stream-2-will-benefit-securitygas-supply-europe/ (accessed on 10 June 2017).

BNS, Lithuania, Denmark to press Brussels over Nord Stream 2, Delfi. https:// en.delfi.lt/nordic-baltic/lithuania-denmark-to-press-brussels-over-nord-stream2.d?id=75875977 (accessed on 1 April 2017).

Borger, J. Finland says it is nearing security deal with US amid concerns over Russia. The Guardian. https:/www.theguardian.com/world/2016/aug/22/finland-us-russiamilitary-security (accessed on 6 June 2017).

Coffey, L. and Kochis, D. The Role of Sweden and Finland in NATO's Defense of the Baltic States. The Heritage Foundation. http://www.heritage.org/europe/report/the-rolesweden-and-finland-natos-defense-the-baltic-states (accessed on 15 December 2017).

European Commission, Recommendation for a Council Decision authorizing the opening of negotiations on an agreement between the European Union and Russian Federation on the operation of the Nord Stream 2 pipeline, 2017. https://www.consilium.europa.eu/register/en/content/out/?typ=SET\&i= ADV $\&$ RESULTSET $=1 \& D O C \_$TITLE $=\& C O N T E N T S=\& D O C \_I D=10249 \% 2 \mathrm{~F} 17 \& D O S$ INTERINST $=\&$ DOC_SUBJECT $=\& D O C \_S U B T Y P E=\& D O C \_D A T E=\&$ document date_from_date $=\&$ document_date_from_date_submit $=\&$ document_date 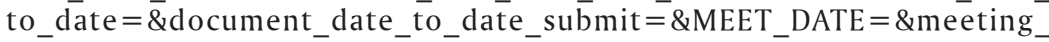

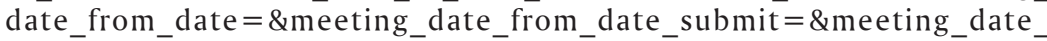
to_date $=\&$ meeting_date_to_date_submit $=\& D \overline{O C} \_L A N C D=E N \& R O W S P P=$ $25 \&$ NRROWS $=500 \&$ ORDERBY $=$ DOC_DATE + DESC (accessed on 12 July 2017)

EUROSTAT. Share of renewables in energy consumption in the EU rose further to $16 \%$ in 2014, EC Europa, February 10, 2016 http://ec.europa.eu/eurostat/documents/ 2995521/7155577/8-10022016-AP-EN.pdf/38bf822f-8adf-4e54-b9c687b342ead339 (accessed on 7 June 2017).

Frühling, S. and Lasconjarias, G. (2016), NATO, A2/AD and the Kaliningrad Challenge, Survival, Vol. 58, Iss. 2, pp. 95-116.

Gasum, Finland's first LNG import terminal opened - provides access to LNG deliveries also outside the gas pipeline network, Gasum, September 10, 2016. https://www. gasum.com/en/About-gasum/for-the-media/News/2016/Finlands-first-LNG-importterminal-opened-provides-access-to-LNG-deliveries-also-outside-the-gas-pipelinenetwork/ (accessed on 10 June, 2017). 
Goldthau, A. (2016), Assessing Nord Stream 2: Regulation, Geopolitics and Energy Security in the EU, Central Eastern Europe and the UK, Strategy Paper 10, London, King's College, pp. 12-45.

Gotkowska, J. and Szymański, P. Between co-operation and membership. Sweden and Finland's relations with NATO, OSW Studies. www.osw.waw.pl (accessed on 23 November 2017).

Gotkowska, J. and Szymański, P. Gotland and Åland on the Baltic chessboard - Swedish and Finnish concerns, OSW Analyses. www.osw.waw.pl (accessed on 12 December 2016).

Gotkowska, J. and Szymański, P. The Nordic countries on Nord Stream 2: between scepticism and neutrality, OSW Analyses. https:/www.osw.waw.pl/en/publikacje/oswcommentary/2016-10-12/nordic-countries-nord-stream-2-between-scepticismand (accessed on 12 October 2016).

Jabri, P. Moscow, EU warns US after House votes for new Russia sanctions. Business Recorder. http://www.brecorder.com/2017/07/26/361476/moscow-eu-warns-us-afterhouse-votes-for-new-russia-sanctions/ (accessed on 26 July 2017).

Jakóbik, W. Time is on the side of Nord Stream 2's opponents, New Eastern Europe. http://www.neweasterneurope.eu/interviews/1890-time-is-on-the-side-of-nordstream-2-s-opponents (accessed on 16 February, 2016).

Kamps, M. (2009, January 10). "Soome dotsent: Nord Streamil on sõjaline tähendus". Majandus Postimees. January 10, 2009. http://majandus24.postimees.ee/67543/ soome-dotsent-nord-streamil-on-sojaline-tahendus, (accessed on 9 June 2017).

Kirk, Lisbeth \& Rettman, Andrew, "New Danish law could block Russian pipeline", The EUObserver, 2017. https://euobserver.com/nordic/139382 https://euobserver.com/ nordic/139382 (accessed on 18 October 2017).

Kolyako, N. Putin urged Finland to support Nord Stream gas pipeline project. The Baltic Course, June 04, 2009. http:/www.baltic-course.com/eng/transport/?doc $=14503$ (accessed 9 June 2017).

Korteweg, R. Nord Stream 2 will divide the EU, but new US sanctions will do more harm. EURACTIV, July 26, 2017. https://www.euractiv.com/section/energy/opinion/ nord-stream-2-will-divide-the-eu-but-new-us-sanctions-will-do-more-harm/ (accessed on 28 September 2017).

Lang, K. O. and Westphal, K. (2017), Nord Stream 2 - A Political and Economic Contextualization, SWP Research Paper, Berlin, German Institute for International and Security Affairs.

Lasconjarias, G. and Marrone, A. (2016), How to Respond to Anti-Access/Area Denial (A2/AD)? Towards a NATO Counter-A2/AD Strategy, NATO Defence College Conference Report. Rome, NATO Defence College, pp. 2-12

Łoskot-Strachota, A. and Groszkowski, J. Gazprom's negotiations with Eustream on Nord Stream 2, Center for Eastern Studies. https://www.osw.waw.pl/en/publikacje/ analyses/2016-07-13/gazproms-negotiations-eustream-nord-stream-2 (accessed on 18 July 2017)

Łoskot-Strachota, A., Kardaś, S. and Szymański, P. The European Commission is ready to talk to Russia about Nord Stream 2, Center for Eastern Studies. https://www.osw. waw.pl/en/publikacje/analyses/2017-04-05/european-commission-ready-to-talk-torussia-about-nord-stream-2 (accessed on 18 April 2017) 
Łoskot-Strachota, A. The European Commission seeks a mandate to conduct talks with Russia on Nord Stream 2, Center for Eastern Studies. https:/www.osw.waw. pl/en/publikacje/analyses/2017-06-28/european-commission-seeks-a-mandate-toconduct-talks-russia-nord (accessed on 26 June 2017)

Lucas, E.The Coming Storm. Baltic Sea Security Report”, Center for European Policy Analysis, http://cepa.org/sites/default/files/styles/medium/Baltic\%20Sea\%20Security\% 20Report-\%20(2).compressed.pdf (accessed 12 December 2015)

Nord Stream AG. Environmental Impact Assessment Report, Nord Stream 2, April 3, 2017. https://www.nord-stream2.com/en/download/document/72/ (accessed on: 7 June 2017)

Polyakova, A. and Laurelle, M. (2016), The Kremlin's Trojan Horses: Russian Influence in France, Germany and the United Kingdom", Atlantic Council Eurasia Center. pp. 5-15

Popławski, K. German energy companies lobby for Nord Stream 2, OSW- Ośrodek Studiów Wschodnich, 21 September 2016. https://www.osw.waw.pl/en/publikacje/ analyses/2016-09-21/german-energy-companies-lobby-nord-stream-2 (accessed on 21 July 2017)

Riley, A. (2016), Nord Stream 2: A Legal and Policy Analysis”, CEPS Special Report No. 151, Brussels, Center for European and Policy Studies.

Schmidt-Felzmann, A. (2016), On Opposite Shores, Not Just Geographically: German and Swedish Perspectives on Nord Stream and Energy Insecurity with Russia in the Baltic Sea Region. In: The Baltic Sea Region: Hard and Soft Security Reconsidered, Latvia Institute of International Affairs.

Schmidt-Felzmann, A. (2017), Russia's military aggression and the security threats posed by "purely commercial" projects in the Baltic Sea Region, Baltic Rim Economies, Pan-European Institute.

Shandra, A. and Virkki, P. Lustration in Finland? Explaining the Issue, Euromaidan Press, 5 July 2016 http://euromaidanpress.com/2016/07/05/lustration-in-finlandexplaining-the-issue/\# arvlbdata (accessed on 9 June 2017)

Sytas, A. EU leaders sign letter objecting to Nord Stream-2 gas link, Reuters. http:// uk.reuters.com/article/uk-eu-energy-nordstream/eu-leaders-sign-letter-objectingto-nord-stream-2-gas-link-idUKKCNOWI1YV (accessed on 17 March 2016).

Teffer, P. Tusk: Nord Stream II doesn't help. EUobserver. December 18, 2015. https:// euobserver.com/energy/131605 (accessed on 8 June 2017)

Williams, I. The Russia - NATO A2AD Environment, CSIS Missile Defense Project, 2017. www.missilethreat.csis.org (accessed on 4 January 2017). 